\title{
Between a Double Crisis: Precarization, Extractivism and the Futures of the Commonist Politics
}

To celebrate the $10^{\text {th }}$ anniversary of Praktyka Teoretyczna journal, we have invited our long-lasting collaborators and comrades to reflect once again on the concept of the common and it's possible futures by posing following questions: a) what is the most important aspect of the current struggles for the common?; b) what are the biggest challenges for the commonist politics of the future?; and c) where in the ongoing struggles do you see a potential for scaling-up and spreading the organisation based on the common? In his reply, Felipe Ziotti Narita situates his answer in the context of contemporary double capitalist crisis, which renders visible the commons as crucial for satisfying collective needs and purposes.

Keywords: the commons, reproduction, double capitalist crisis, precarization, extractivism 


\section{What is the most important aspect of the current struggles for the common?}

The current struggles for the common are situated between a double capitalist crisis: the scars of the 2008 financial crisis and the crisis of social reproduction due to the COVID-19 pandemic. In this crisscross, one of the most important aspects is the sense of expanded precarization of forms of life. The issue here is the effects of successive economic crises and austerity policies on labor, salaries, social inequalities and social insecurity due to the dilapidation of welfare policies, but also about a loss of the means of living together, for example, with the private appropriation of former public sectors and common goods (like education and health). Theodor Adorno had an interesting expression to describe the malaise of capitalist socialization: "damaged life" (beschädigtes Leben), that is, the precarization of social experiences is a total fact that extends simultaneously from work to personal affairs and from institutions to the lifeworld. Ken Loach's Sorry We Missed You illustrates exactly this mood: the new global norm is a kind of generalized insecurity that produces a fragmented livelihood under the pressures of flexibility, unpredictability, etc.

Here and there, some collectives are leading new moves of grassroots political conflict against the precarization of forms of life. They address a diffuse set of problems that emphasize cooperation and commons-based community management. A good example is the network of transnational social movement EuroMayDay, which started as a political platform against precarity (especially in labor relations and migrant conditions) and defends public transport and the knowledge available on the Internet as common resources for collectivities. With the COVID-19 crisis, manufacturing groups in many countries (I received some info from comrades in Greece, Spain, and Brazil) started producing facemasks and visors grounded in a community-based production - the products have been circulating for free and a good example is the network Coronavirus Makers. This kind of open-source technology questions the capitalist regime of applied knowledge (dependent on for-profit techniques) and articulates the struggle for the commons in light of the strong precarization of unequal access to raw materials in many countries.

Precarization is also connected to the appropriation of digital infrastructure. Capitalist modernizing moves unleashed a vast digital and network milieu grounded in many cooperative tasks that deterritorialized social production into circuits and, with the gig economy, offered a partial response to the crisis of accumulation in the wake of the 2008 
crisis. Under the aegis of capital, and mediated by networks, the subsumption of social reproduction and labor to the valorization process has co-opted each piece of socialization. On the other hand, it also favored many experiences of peer production and horizontal reciprocity that have been challenging profit-maximization and connecting different subjective experiences of precarity. In July 2020, amidst the pandemic, workers from iFood, Uber Eats and Rappi in Brazil decided to paralyze their activities and organize a public demonstration against labor conditions in the biggest Brazilian cities - with the pandemic, they were among the most vulnerable workers to contagion and could not count on social security. Similar demonstrations already had taken place in 2019-2020 in Colombia, Argentina and Chile. In light of the need for dignity in labor process, the events connect a moral demand from workers to their material subsistence and, above all, address how the grammar of "partnership" in the gig economy is a kind of kidnapping of the network cooperative practices that have emerged since the 1990s with immaterial labor.

\section{What are the biggest challenges for the commonist politics of the future?}

The political agency with regard to the common is always a critical collective project. This general definition has many theoretical and practical consequences. Two topics are interesting to consider in terms of the political prospects.

Firstly, commonist politics must always reflect on the question concerning what it means to be critical. Alfred Schmidt holds that the critical social sciences must make a historical diagnosis of a condition to be transcended. Critique deals with the latent prospects of emancipation that remain subsumed under capitalist reproduction. A distinctive achievement of Marx's Paris manuscripts of 1844 is the critique of private appropriation pari passu with the impact of capitalist market relations on subjectivity and socialization. Sociality is mediated by capital and money, and it interpellates the individual with the extension of needs (Bedürfnisse) and moral pressures to enter into an asymmetrical relationship among owners. Over the last four decades, the expansion of financial capital and market structures through public institutions and the commons has made everything commodified, from knowledge to material goods. Individuals, thus, enter into socialization as needy subjects: their autonomy exists only precariously (prekär), since their

Firstly, commonist politics must always reflect on the question concerning what it means to be critical. 
subsistence depends on market relations. In this sense, the commonist politics must deal with a critique that is also concerned with denouncing the precarity of human autonomy under market-oriented structures.

A major political challenge is to grasp the historical task and articu-

On the one hand, commonist politics has to take into account the need for a positive role of social identity, since difference and pluralism are unavoidable pro-

ducts of capitalist globalization and will fuel political conflicts and far-right move-

ments in national societies. On the other

hand, sustainable projects for the material subsistence of individuals will demand local and transnational practices of redistribution of social goods grounded in the sharing of resources, solidarity, cooperation and open access to knowledge,

trying to erode the mediations of capital. late a critical discourse that fits with it. An important dimension may be mapped according to Nancy Fraser's effort at actualizing our political grammar by complementing recognition with redistribution. On the one hand, commonist politics has to take into account the need for a positive role of social identity, since difference and pluralism are unavoidable products of capitalist globalization and will fuel political conflicts and far-right movements in national societies. On the other hand, sustainable projects for the material subsistence of individuals will demand local and transnational practices of redistribution of social goods grounded in the sharing of resources, solidarity, cooperation and open access to knowledge, trying to erode the mediations of capital.

All those practices are latent in many experiences across the world, ironically, beneath the strong expansion of capitalist network infrastructures. But it is an illusion to adopt a spontaneous view of emancipation, as if commonist politics would take place on its own or be conducted by an alleged conciliatory, reformist discourse. And this leads my answer to the second topic, which deals with what it means to be a collective project. What constitutes the common is not the object per se (water, software, etc.), but the kind of political relation that underlies the modes of use and management of the objects. It is a political contract with a new substance: not individualistic agreement, nor the relation among owners (like the liberal versions of the contract), but rather a defense of the social control over resources according to collective needs and purposes. The notion of the institution of the common emphasizes the action and the historical conditions for the implementation of a political project that dialectically creates a new social organization grounded in horizontal forces of production and the search for autonomy against the heteronomy imposed by market and state. It is dialectical, since it can emerge from unresolved capitalist contradictions: cooperative practices and network infrastructures coopted by capital contain potential transformations that confront the order of things with the consciousness of the common. As Adorno states in Zur Metakritik der Erkenntnistheorie, the old mediates the production of the new, which maintains the old as a moment of the mediation.

The practical challenge for the commonist politics of the future is how to maintain a sustainable, perennial mobilization. In a recent article, Donatella Della Porta argues that the current multiple crises 
have opened up the need for the collective and participatory management of the commons, comprising public health, mobility, education, food policy, and housing policy. She appropriately points out that commonist politics can learn from the mobilization of civil society and the logics of social movements. Social movements tend to grow with political opportunities for gradual transformation. In times of deep crises and expanded precarization, mobilizations are fueled by the sense of drastic deterioration in life conditions, due to a much wider spectrum of problems. In this context, a single problem can pull the trigger of many other issues - and we see how current social movements and multitudinary mobilization can be operative with these logics, like Black Lives Matter and the Chilean street protests of 2019 and 2020.

However, a challenge remains open: how to direct the resources of mobilization, like skills and infrastructure, towards a commonist perspective. I agree with the recent book of Vangelis Papadimitropoulos, who states that for the commons and peer production to evolve into a tangible project that challenges the capitalist market-led policy, we need income to the commoners and common infrastructures (comprising digital and material support embedded in institutional networks). In light of the technological devices, Silke Helfrich has recently proposed the use of network technologies to connect and federate commons regarding the organization of convivial tools, that is, a kind of use of technology that is not proprietary, but rather open to community needs. In this way, instead of adapting the forms of life to technological and market imperatives, she argues for experiences grounded in how technology can go with collective needs of production and mobilization.

An important issue for commonist politics is how it will be able to dialogue and critically incorporate hacktivism and hacker ethics. Digital commons and open-source software, as a political defense of the autonomy of cyberspace from big-tech oligopolies, also have hacker origins (see Pekka Himanen and Gabriella Coleman). In the 2010s, with the leaks, we saw the political force of hacktivism in public opinion, treating data as a kind of political frontier for the digital commons and the openness of secrecy imposed on public data. It is an institutional dilemma for liberal democracies: civil society tends to demand more and more transparency and accountability from governments, which are reluctant and bureaucratically oriented to impose silence on data. If public policies for open data and the fair use of digital information are institutional responses, hacker ethics provides an opportunity for citizens to let their voice be heard. 
This leads my answer to the digital enclosures of the commons. Here it is worth mentioning a difference in relation to the physical enclosures that unleashed capitalist development in modernity: digital enclosures are not only directed towards natural resources, but rather towards every piece of sociality in cyberspace. In this context, for example, cultural production sets many challenges for commonist politics. Since the 1990s, there have been many anti-copyright movements in artistic sub-cultures (see Dmytri Kleiner and Florian Cramer). A good example is cultural patrimony: the digitalization of physical libraries and museums in partnership with for-profit tech corporations is frightening because it can undermine the notion of cultural commons and their role in social development (especially in education and research). In the late 2000s, when Lewis Hyde and Robert Darnton stated that copyright threatens creativity, they rightly pointed to some alternatives embedded in Public Library of Science and the Internet Archive. We need to expand this logic and see how traditional cultural institutions - like the national libraries of France and Brazil - will manage the open policies of their collections as platforms for the commons.

3. Where in the ongoing struggles do you see a potential for scaling-up and spreading organisation based on the common?

I would like to talk about my context (Latin America) and offer an overview on different dimensions of the potential struggles for the common. The region has been hit hard by the current pandemic, because the crisis has deepened the precarity of already unstable economic activity - even before the pandemic, our major economies (Brazil, Chile, Argentina and Mexico) were not really going through good moments.

The integration of the region into the global productive chains is basically dependent on raw materials. Since the 1980s and the 1990s, deep market reforms have paved the way for finance capital to use the region as a key space for its operations and the territory has been the focus of continual struggles and organizations based on the commons. In 2020, the Latin American Observatory of Environmental Conflicts mapped 92 socioenvironmental conflicts since the early 2000s, due to the appropriation of the commons and territory, comprising mining and agribusiness. The effects of extractivism go hand in hand with the socioeconomic ratio of expansion of market relations and financial capital. Sandro Mezzadra and Bret Nielson called it "operations of capital" and emphasized how extraction policies (mining, oil, clearing of forests 
for the production of biofuels and foodstuffs, etc.) turn the expropriation of territory and common resources into a key issue for the precarization of life. In the 2000s, for example, commoners from the Peruvian provinces of Ayabaca, Huancabamba, Jaén and San Ignacio organized massive protests against mining extraction and its biocultural effects on local producers.

The recent modernization efforts dealing with infrastructure have also involved the expulsions (Saskia Sassen) of populations from their homes - be it via direct state intervention for eviction or due to sociotechnical disasters that force populations to migrate. During the economic boom of Brazil in the early 2010s, the projects for the World Cup, the Olympics and infrastructure are good examples of this scenario: many residents in highly urbanized areas had to vacate without any compensation. In the same context, the dam disasters (in iron ore mines) in Mariana (2015) and Brumadinho (2019) forced people to leave their cities (that remain destroyed) due to the toxic mudflow, with deep impacts on collective resources (rivers and riparian zones) and local producers. Thus, capitalist modernization discourses, which promise a naïve reconciliation with development and abundance, deliver a permanent state of crisis with the expropriation of the commons. These dialectical tragedies revealed the false promises of (neo)developmentalist capitalism in peripheral countries, which combined, in the last decade, state-led interventions in partnership with finance capital (the mines were privatized in the 1990s).

Common-based practices have been spreading through highly urbanized areas, where artist collectives and urban planners have been discussing the sustainability of city life. Several legal documents had already emphasized urban territorial development and the need for commons-based public policies - Law 388 in Colombia (1997), the City Statute in Brazil (2001) and the Ecuadorian constitution of 2008. The right to the city à la Henri Lefebvre, with an emphasis on the collective use and production of urban space instead of the exclusive logics of private appropriation, implies the need for urban commons to promote welfare and mitigate strong socioeconomic inequalities and the precarious conditions of lower classes. It comes as no surprise that mobility, free parks, self-managed cultural spaces, and decent housing policy have been demanded in several street protests in Santiago and São Paulo in recent years. In times of national policies for territorial ordination, which are endorsed by United Nations Economic Commission for Latin America and the Caribbean and the Inter-American Development Bank, and are underway in Brazil, Chile and Costa Rica, urban commons might be

Thus, capitalist modernization discourses, which promise a naïve reconciliation with development and abundance, deliver a permanent state of crisis with the expropriation of the commons. These dialectical tragedies revealed the false promises of (neo) developmentalist capitalism in peripheral countries, which combined, in the last decade, state-led interventions in partnership with finance capital. 
crucial for public policy and could spread many organizations based on the common.

It is also important to highlight the circulation of knowledge. In Brazil, research universities are mostly public universities, which is to say, science is funded by public investments. Here there is a tradition of open access science: the majority of our academic journals are based on the creative commons regime. Knowledge circulates freely and is embedded in databases and provides resources for the planning of public policy, for teaching, and even for public debate. Most of our journals cannot count on the infrastructure of global top-journals and publishers, partly due to the semi-peripheral position of the region (see Fernanda Beigel and Jean-Claude Guédon), but our long experience with open access is more positive than negative. Besides the strong regional circuit of peer-reviewed publications (Latindex, Clacso, Redalyc and Scielo), there are many editorial forums and research groups engaged in supporting open access as a politics for the commons. This kind of struggle is far from grassroots politics and the kind of critique that produces multitudinary mobilization and engagement, but it somehow constitutes a horizon for our public policies on education, culture and science, in times of pressures for the "social relevance" of the public costs of research universities. Especially in a context of fiscal hardship, open science might be a reasonable response that deals with the cultural and intellectual heritage, a common resource that is crucial to the development of our societies - marked by the historical exclusion of popular classes from higher education and only precariously integrated into the education system over the last 30 years. 
FELIPE ZIOTTI NARITA - received a postdoctoral training in the social sciences at the University of São Paulo (USP) and the Federal University of São Carlos (UFSCar) and all four of his degrees from São Paulo State University (UNESP). Lecturer in public policy at UNESP, affiliated editor of Theoretical Practice (Adam Mickiewicz University - Poland), lecturer in social theory at Baron of Mauá University and editor-in-chief of Cadernos CIMEAC (Federal University of Triângulo Mineiro - Brazil). His work is concerned with interdisciplinary research in the social sciences and his research interests include social theory, globalization, contemporary history, social movements, modernity/modernization discourses and history of education. Currently preparing a volume on crisis and globalization (Praktyka Teoretyczna, 2021) and a book on social media and democracy (University of Westminster Press, 2021).

\section{Address:}

São Paulo State University (UNESP)

School of Humanities and Social Sciences

email: felipe.narita@unesp.br

\section{Citation:}

Narita, Felipe Ziotti. 2020. "Between a Double Crisis: Precarization, Extractivism and the Futures of the Commonist Politics." Praktyka Teoretyczna 4(38): 125-133.

DOI: $10.14746 / \operatorname{prt} 2020.4 .6$

\section{Autor: Felipe Ziotti Narita}

Tytuł: W kleszczach podwójnego kryzysu: Prekaryzacja, eksraktyktywizm i przyszłość polityki tego, co wspólne

Abstrakt: Z okazji 10 urodzin Praktyki Teoretycznej zaprosiliśmy naszych wieloletnich współpracowników i towarzyszy do wspólnego rozważenia przyszłości tego, co wspólne. Poprosiliśmy ich o zmierzenie się z następującymi pytaniami: a) co jest najważniejszym aspektem współczesnych walk o to, co wspólne?; b) jakie największe wyzwania stoją w przyszłości przed polityką tego, co wspólne?; c) gdzie w ramach toczonych walk wiedziecie potencjał na rozwijanie i poszerzanie organizacji opartej na tym, co wspólne? Felipe Ziotti Narita umieszcza swoją odpowiedź w kontekście współczesnego podwójnego kryzysu kapitalizmu, który uwidacznia dobra wspólne jako kluczowe z perspektywy zaspokajania kolektywnych potrzeb.

Słowa kluczowe: dobra wspólne, reprodukcja, podwójny kryzys kapitalizmu, prekaryzacja, ekstraktywizm 